\title{
HUBUNGAN KARAKTERISTIK PERMUKIMAN DENGAN BENTUK ADAPTASI MASYARAKAT TERHADAP ROB DI PESISIR KOTA SEMARANG
}

\section{RELATIONSHIP BETWEEN SETTLEMENT CHARACTERISTICS AND COMMUNITY ADAPTATION TOWARDS ROBS IN COASTAL OF SEMARANG CITY}

\author{
Tazri Mintiea', Bitta Piggawati ${ }^{2}$ \\ 'Departemen Perencanaan Wilayah dan Kota; Universitas Diponegoro, Semarang, Jawa Tengah; tazrimintieaaa@gmail.com \\ ${ }^{2}$ Departemen Perencanaan Wilayah dan Kota; Universitas Diponegoro, Semarang, Jawa Tengah; bitta.pigawati@gmail.com
} Info Artikel:

- Artikel Masuk: 13/09/2018

\section{ABSTRAK}

Perkembangan Pinggiran Kota Semarang meningkat cepat ditandai dengan meningkatnya laju pertumbuhan penduduk di kawasan pesisir Kota Semarang. Kawasan pesisir Kota Semarang berfungsi sebagai pusat perdagangan dan jasa, pusat kegiatan industri dan sebagai simpul utama transportasi Pulau Jawa. Meningkatnya laju pertumbuhan penduduk dan terkonsentrasinya kegiatan di kawasan pesisir Kota Semarang mengakibatkan perkembangan permukiman cepat dari tahun ke tahun. Salah satu kawasan pesisir yang mengalami perkembangan permukiman relatif cepat adalah Kecamatan Genuk. Kondisi ini dapat diketahui berdasarkan adanya penambahan luas permukiman selama kurun waktu 10 tahun (2007-2017). Kawasan permukiman di Kecamatan Genuk merupakan kawasan yang sering mengalami banjir rob sehingga mengakibatkan kerusakan fisik permukiman dan infrastruktur. Perbedaan kemampuan adaptapi mengakibatkan adanya perbedaan tingkat kerentanan masyarakat terhadap bencana rob. Bentuk adaptasi juga dapat dipengaruhi oleh karakteristik fisik lingkungan permukiman. Sehingga perlu dikaji hubungan karakteristik permukiman dengan bentuk adaptasi masyarakat pesisir di Kecamatan Genuk, Kota Semarang. Metode penelitian ini adalah metode kuantitatif dengan teknik analisis deskriptif kuantitatif, analisis spasial, analisis skoring dan analisis korelasi Spearman. Penelitian ini lebih difokuskan pada mengkaji hubungan bentuk adaptasi dengan aspek fisik, berbeda dengan penelitian sebelumnya yang lebih banyak membahas mengenai aspek non fisik. Hasil analisis menunjukkan bahwa terdapat hubungan yang kuat antara karakteristik fisik permukiman dengan bentuk adaptasi masyarakat terhadap rob (nilai koefisien korelasi = 0,535).

Kata Kunci : Kawasan Pesisir; Karakteristik Permukiman; Adaptasi

\section{ABSTRACT}

The development of Semarang Suburbs is increasing rapidly as seen from the increasing rate of population growth in the coastal area of Semarang City. The coastal area of Semarang City serves as the center of trade and services, the center of industrial activities and as the main node of transportation for Java Island. The increasing rate of population growth and the concentration of activities in the coastal area of Semarang City has led to the rapid development of settlements continuously. One of the coastal areas that experienced the development of settlements relatively fast is Genuk District. This condition can be known based on the addition of settlement area over a period of 10 years (2007-2017). The settlement of Genuk District is an area that often experiences rob flooding causes physical damage of settlements and damage of settlement infrastructure. Differences in adaptive ability lead to differences in the level of vulnerability of the community to the rob disaster. The type of adaptation can also be influenced by the characteristics of the settlement environment. So it is necessary to study the characteristics of settlements based on type of adaptation of coastal communities in the Genuk District of Semarang City. The method in this study is a quantitative method with quantitative descriptive analysis techniques, spatial analysis, scoring analysis and Spearman correlation analysis. This research is focused on knowing the relationship between type of adaptation and physical aspects, contrast to previous studies that discussed about nonphysical. The results show that there is a fairly strong relationship between the physical characteristics of the settlement and the pattern of community adaptation to flood rob (correlation coefficient value $=0,535$ ).

Keyword: Coastal Area; Characteristics Of Settlements; Adaptation

Copyright $\odot 2018$ JPWK-UNDIP This open access article is distributed under a Creative Commons Attribution (CC-BY-NC-SA) 4.0 International license.

Cara men-sitasi:

Mintiea, Tazri, \& Pigawati, Bitta. (2018). Hubungan Karakteristik Permukiman Dengan Bentuk Adaptasi Masyarakat Terhadap Rob Di

Pesisir Semarang, vol 14 (3), 199-212 


\section{PENDAHULUAN}

Kota Semarang sebagai ibukota Provinsi Jawa Tengah menjadi salah satu koridor pembangunan wilayah yaitu dengan adanya koridor pantai utara (pelabuhan) sebagai simpul pintu gerbang pembangunan dan simpul transportasi utama Pulau Jawa dengan garis pantai sepanjang kurang lebih 25 kilometer. Perkembangan Pinggiran Kota Semarang ditandai dengan meningkatnya laju pertumbuhan penduduk di kawasan pesisir Kota Semarang. Kawasan pesisir merupakan wilayah perbatasan tempat berubahnya dua lingkungan utama, yaitu laut dan daratan, sehingga kawasan pesisir memiliki ciri khas wilayah tersendiri (Jens C. Sorensen 1990). Kawasan pesisir Kota Semarang memiliki fungsi sebagai pusat perdagangan dan jasa, kegiatan industri dan transportasi. Pertumbuhan penduduk yang cepat dan perpindahan penduduk dari desa ke kota mengakibatkan beberapa wilayah menjadi tujuan penduduk untuk bermukim tanpa memempertimbangkan kemampuan kawasannya (Jaitman and Brakarz 2013). Permukiman merupakan lokasi khusus untuk tempat tinggal dan melakukan aktivitas ekonomi, politik, dan kegiatan budaya, permukiman merupakan pendorong utama penggunaan lahan dan dasar tutupan lahan (Zhang et al. 2014). Permukiman erat kaitannya dengan kondisi fisik alam, bangunan dan sosial ekonomi masyarakat sekitar (Turner and Fichter 1972).

Kawasan pesisir sebagai daerah pengelolaan ekosistem laut dapat berubah fungsinya menjadi kawasan permukiman yang padat penduduk dikarenakan konsentrasinya kegiatan di kawasan pesisir Kota Semarang. Lingkungan permukiman kawasan pesisir memiliki daya tarik yang bervariasi untuk ditinggali (Perlman 1980). Namun, kawasan pesisir dianggap rentan karena memiliki ekosistem, geomorfologi dan kompleksitas yang tinggi, serta menjadi wilayah bercampurnya kegiatan sosial dan ekonomi (Lins-deBarros 2017). Perubahan fungsi kawasan pesisir yang tidak didukung dengan sarana dan prasarana lingkungan yang memadai dapat menyebabkan menurunnya kualitas permukiman. Peristiwa kenaikan muka air laut dan penurunan muka tanah memengaruhi dampak peningkatan ancaman bencana banjir rob di kawasan pesisir Kota Semarang. Salah satu daerah paling rawan terhadap bencana rob di kawasan pesisir Kota Semarang yaitu Kecamatan Genuk. Sebanyak 10 kelurahan di Kecamatan Genuk menjadi daerah rawan banjir di Kota Semarang dengan tingkat ancaman genangan tinggi, sedang dan rendah (Badan Penanggulangan Bencana Daerah 2018). Bencana banjir rob telah merubah kondisi fisik lingkungan, sehingga memberikan dampak negatif yang cukup signifikan bagi masyarakat, bangunan dan infrastruktur permukiman yang ada di kawasan pesisir (Suryanti dan Marfai 2008).

Terdapat perbedaan respon masyarakat dalam menghadapi ancaman bencana banjir rob. Salah satu upaya masyarakat dalam merespon dampak lingkungan yang diterima akibat perubahan iklim disebut dengan adaptasi (Syah 2012). Adaptasi termasuk tindakan yang diambil untuk mengurangi kerentanan dan meningkatkan resiliensi, sedangkan kemampuan adaptasi adalah kemampuan untuk mengambil tindakan tersebut (Smit \& Wandel 2006). Kemampuan adaptasi masyarakat ditentukan oleh kemampuan ekonomi, pengetahuan, pengalaman dan respon masyarakat terhadap kondisi lingkungan (Adger dan Vincent 2005). Perbedaan kondisi masyarakat dapat menghasilkan berbagai bentuk adaptasi yang berbeda terhadap bencana rob di Kecamatan Genuk. Bentuk adaptasi juga dapat dipengaruhi oleh kondisi lingkungan permukiman. Pada kondisi lingkungan permukiman yang kurang nyaman, masyarakat dihadapkan pada dua pilihan yaitu tetap bertahan atau pindah ke lingkungan yang lebih baik (Riska dan Yuliastuti 2013). Kondisi fisik lingkungan permukiman yang berbeda dapat memengaruhi perbedaan bentuk adaptasi masyarakat terhadap bencana rob di suatu wilayah. Penelitian ini bertujuan untuk mengetahui hubungan antara kondisi fisik lingkungan permukiman dengan bentuk adaptasi masyarakat terhadap bencana rob di Kecamatan Genuk.

Penelitian sebelumnya mengenai pola adaptasi masyarakat pesisir telah diteliti oleh Wijaya dan Sariffudin (2014) bahwa terdapat tiga bentuk adaptasi masyarakat yang dipengaruhi oleh kemampuan ekonomi yaitu menerima kondisi lingkungan permukiman, peninggian lantai rumah dan peninggian rumah. Masyarakat kelas menengah ke atas melakukan upaya adaptasi yang baik dipengaruhi perhatian yang besar terhadap kualitas lingkungan. Penelitian Pradoto dan Piggawati (2014) menunjukkan kebertahanan masyarakat pesisir ini berkaitan dengan pola adaptasi dalam merespon kualitas lingkungan permukiman 
pesisir. Kelompok masyarakat dengan tingkat kebertahanan rendah bisa dikatakan memiliki tingkat ketergantungan yang rendah terhadap lingkungan tempat tinggalnya yang berada didaerah banjir rob. Sedangkan penelitian Suryanti dan Marfai (2008) menunjukkan beberapa bentuk adaptasi terhadap rob dan alasan masyarakat tetap tinggal di lingkungan rawan bencana rob. Ketika suatu masyarakat mulai menyesuaikan diri terhadap lingkungan yang baru, suatu proses perubahan akan dimulai dan mungkin membutuhkan waktu yang lama untuk dapat menyesuaikan diri (Moran 2018). Upaya masyarakat menyesuaikan diri di masing-masing permukiman rawan bencana dapat berbeda-beda. Oleh karena itu, penelitian ini lebih difokuskan pada mengkaji hubungan bentuk adaptasi dengan aspek fisik permukiman, berbeda dengan penelitian sebelumnya yang hanya menunjukkan bentuk adaptasi terhadap bencana lebih dipengaruhi oleh aspek non fisik.

\section{DATA DAN METODE}

Kawasan permukiman di Kecamatan Genuk yang menjadi wilayah penelitian yaitu kawasan permukiman yang berada di Kelurahan Muktiharjo Lor, Gebangsari, Genuksari, Banjardowo, Trimulyo, Terboyo Wetan dan Terboyo Kulon. Wilayah tersebut merupakan merupakan kawasan permukiman pesisir yang terkena dampak rob dengan sifat kerawanan bencana banjir rob sangat rawan yaitu dengan ketinggian genangan >1,5 m. Berikut wilayah penelitian Kecamatan Genuk Kota Semarang.

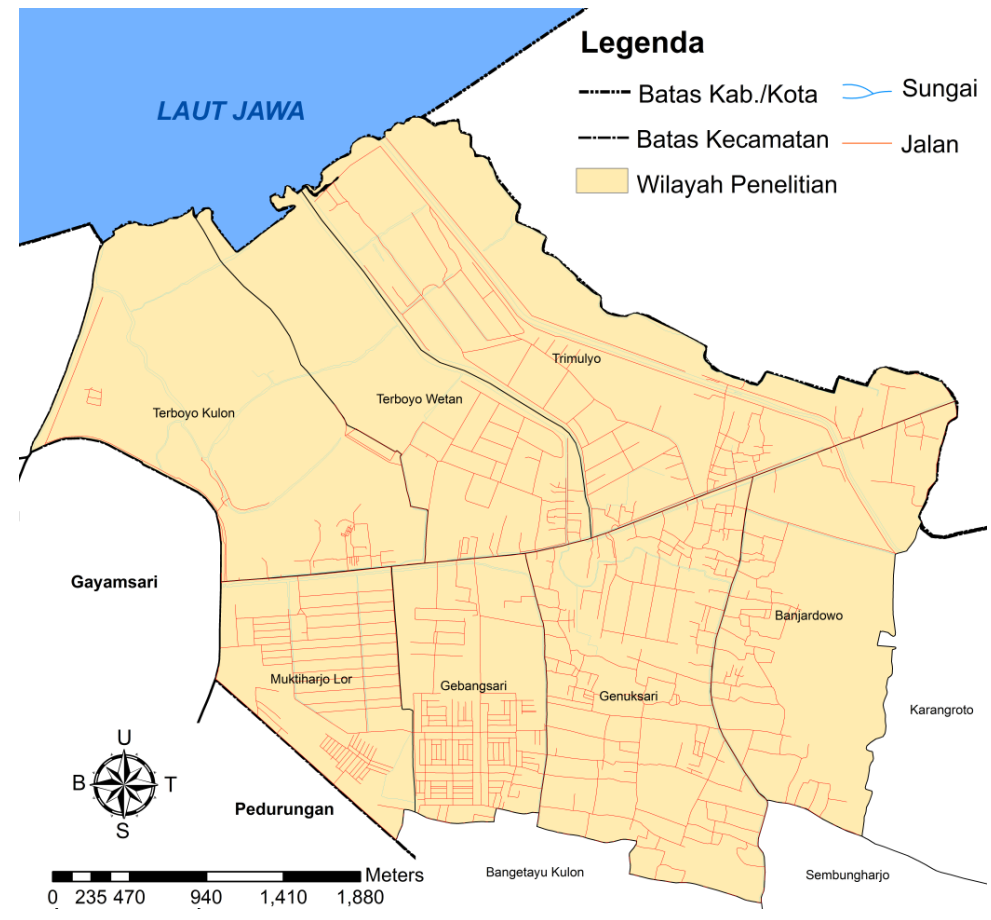

Gambar 1. Wilayah Penelitian (Hasil Analisis, 2018)

Sebagian besar rumah masyarakat di permukiman pesisir Kecamatan Genuk memiliki konstruksi bangunan rumah yang layak. Hal tersebut ditunjukkan oleh jumlah rumah dengan jenis material bangunan tembok lebih banyak dari pada jenis material bangunan bambu/kayu. Namun, hampir seluruh rumah di Kelurahan Trimulyo, Terboyo Kulon, dan Terboyo Wetan bersifat semi permanen dan mengalami kerusakan yang parah akibat banjir rob. Pada wilayah tersebut luas lantai rumah didominasi dengan luas 50-100 $\mathrm{m}^{2}$ dan dihuni oleh lebih dari $1 \mathrm{KK}$. Sedangkan pada Kelurahan Muktiharjo Lor, Gebangsari, Genuksari dan Banjardowo sebagian besar rumah bersifat permanen dengan rata-rata luas lantai rumah > $100 \mathrm{~m}^{2}$. 

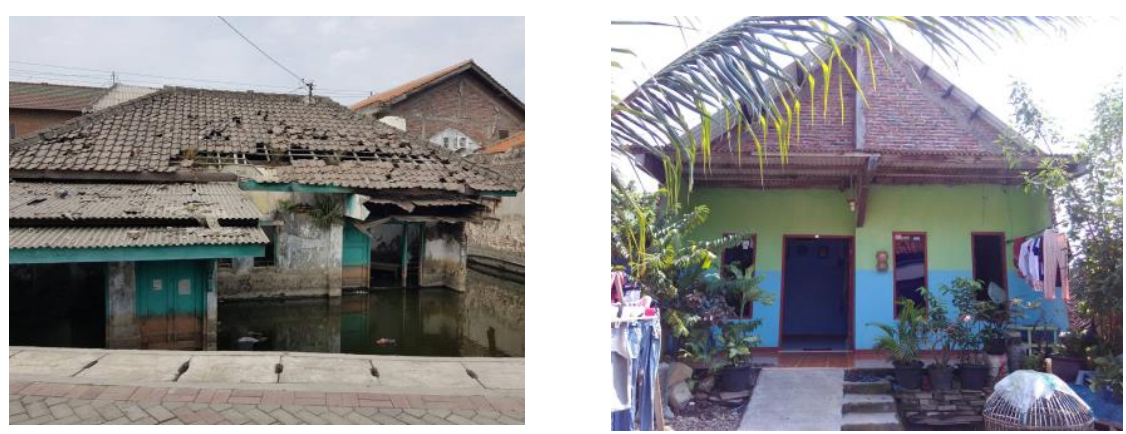

Gambar 2. Kondisi Rumah di Kecamatan Genuk (Hasil Observasi, 2018)

Penelitian ini menggunakan pendekatan kuantitatif. Sumber data terdiri dari dua jenis yaitu data primer dan data sekunder. Teknik pengambilan sampel menggunakan teknik stratified random sampling. Teknik pengumpulan data terdiri dari kuesioner, observasi dan studi literatur. Jumlah sampel yang digunakan dalam penelitian adalah 100 sampel. Adapun sampel yang digunakan dalam pengumpulan data di Kecamatan Genuk dapat dilihat pada Tabel 1.

Tabel 1. Distribusi Penyebaran Kuesioner (Hasil Analisis, 2018)

\begin{tabular}{|l|l|c|c|}
\hline \multirow{2}{*}{ Kelas } & \multicolumn{1}{|c|}{ Kelurahan } & Rumah Tangga & Jumlah Sampel \\
\hline \multirow{3}{*}{$\begin{array}{l}\text { Tinggi } \\
\text { Genangan }>0,75 \mathrm{~m}\end{array}$} & Trimulyo & 1109 & 32 \\
\cline { 2 - 4 } & Terboyo Kulon & 173 & 5 \\
\cline { 2 - 4 } & Terboyo Wetan & 458 & 13 \\
\cline { 2 - 4 } & Jumlah & $\mathbf{1 0 0 1 5}$ & $\mathbf{5 0}$ \\
\hline \multirow{3}{*}{$\begin{array}{l}\text { Rendah : } \\
\text { Genangan }<0,75 \mathrm{~m}\end{array}$} & Muktiharjo Lor & 1220 & 6 \\
\cline { 2 - 4 } & Gebangsari & 2102 & 10 \\
\cline { 2 - 4 } & Genuksari & 4953 & $\mathbf{2 3}$ \\
\cline { 2 - 4 } & Banjardowo & $\mathbf{2 2 7 1}$ & $\mathbf{5 0}$ \\
\cline { 2 - 4 } & Jumlah & $\mathbf{1 0 7 3 5}$ & \\
\hline
\end{tabular}

Metode analisis dilakukan dengan teknik analisis deskriptif kuantitatif, analisis spasial, analisis skoring, dan analisis korelasi Spearman.

2.1 Analisis perkembangan penggunaan lahan permukiman Kecamatan Genuk

Analisis ini digunakan untuk mengetahui perkembangan penggunaan lahan permukiman dalam kurun waktu 10 tahun (2007-2017). Teknik analisis yang digunakan adalah teknik spasial. Analisis spasial adalah sekumpulan teknik yang dapat digunakan dalam pengolahan data SIG (Kemenristek RI, 2013). Variabel atau data yang digunakan adalah luas penggunaan lahan permukiman tahun 2007-2017. Hasil dari analisis ini berupa luasan perkembangan penggunaan lahan permukiman dalam kurun waktu 10 tahun.

\subsection{Analisis karakteristik permukiman}

Analisis ini digunakan untuk mengetahui karakteristik permukiman yang ada di kawasan rawan bencana rob Kecamatan Genuk. Teknik analisis yang digunakan adalah analisis skoring. Panduan penilaian dan pemberian skor dilakukan dengan pendekatan skala Likert. Skala likert digunakan untuk mengukur sikap, pendapat dan persepsi seseorang atau sekelompok orang tentang fenomena sosial (Sugiyono 2010). 
A. Analisis kondisi fisik pemukiman di 7 (tujuh) kelurahan di kawasan pesisir Kecamatan Genuk. Variabel yang digunakan yaitu kepadatan hunian, luas lantai bangunan dan kondisi bangunan berdasarkan jenis material bangunan (Tabel 2).

Tabel 2. Variabel dan Kriteria Kondisi Fisik Permukiman (Hasil Analisis, 2018)

\begin{tabular}{|c|c|c|c|c|}
\hline Kepadatan Bangunan & $\begin{array}{l}\text { Luas Lantai } \\
\text { Bangunan }\end{array}$ & Kondisi Bangunan & Kriteria & $\begin{array}{l}\text { Harkat } \\
\text { (Skor) }\end{array}$ \\
\hline $\begin{array}{l}\text { Kepadatan rumah rata-rata } \\
\text { pada permukiman } \\
(<40 \%)\end{array}$ & $\begin{array}{l}\text { Luas lantai rumah } 50- \\
100 \mathrm{~m}^{2} \text { sebanyak } 21 \%- \\
37 \%\end{array}$ & $\begin{array}{l}\text { Tingkat permanensi } \\
\text { bangunan tinggi }(75 \%- \\
87 \%)\end{array}$ & Baik & 3 \\
\hline $\begin{array}{l}\text { Kepadatan rumah rata-rata } \\
\text { pada permukiman sedang } \\
(<40 \%-60 \%)\end{array}$ & $\begin{array}{l}\text { Luas lantai rumah } 50- \\
100 \mathrm{~m}^{2} \text { sebanyak } 38 \%- \\
54 \%\end{array}$ & $\begin{array}{l}\text { Tingkat permanensi } \\
\text { bangunan sedang (61\%- } \\
74 \%)\end{array}$ & $\begin{array}{l}\text { Cukup } \\
\text { Baik }\end{array}$ & 2 \\
\hline $\begin{array}{l}\text { Kepadatan rumah rata-rata } \\
\text { pada permukiman } \\
(>60 \%)\end{array}$ & $\begin{array}{l}\text { Luas lantai rumah } 50- \\
100 \mathrm{~m}^{2} \text { sebanyak } 55 \%- \\
71 \%\end{array}$ & $\begin{array}{l}\text { Tingkat permanensi } \\
\text { bangunan rendah ( } 47 \% \text { - } \\
60 \%)\end{array}$ & Buruk & 1 \\
\hline
\end{tabular}

B. Analisis ketersediaan sarana lingkungan permukiman. Jenis sarana permukiman yang dianalisis ini adalah sarana pendidikan, sarana kesehatan dan sarana perdagangan dan jasa (Tabel 3).

Tabel 3. Variabel dan Kriteria Ketersediaan Sarana Lingkungan (Hasil Analisis, 2018)

\begin{tabular}{|l|c|c|}
\hline \multicolumn{1}{|c|}{ Sarana Lingkungan } & Kriteria & $\begin{array}{c}\text { Harkat } \\
\text { (Skor) }\end{array}$ \\
\hline $\begin{array}{l}\text { Jumlah sarana yang tersedia sudah dapat melayani jumlah kebutuhan } \\
\text { penduduk }\end{array}$ & Memadai & 3 \\
\hline $\begin{array}{l}\text { Jumlah sarana yang tersedia cukup melayani jumlah kebutuhan } \\
\text { penduduk }\end{array}$ & $\begin{array}{c}\text { Cukup } \\
\text { Memadai }\end{array}$ & 2 \\
\hline $\begin{array}{l}\text { Jumlah sarana yang tersedia belum dapat melayani jumlah kebutuhan } \\
\text { penduduk }\end{array}$ & $\begin{array}{c}\text { Kurang } \\
\text { Memadai }\end{array}$ & 1 \\
\hline
\end{tabular}

C. Analisis ketersediaan dan kondisi prasarana lingkungan permukiman. Jenis prasarana permukiman yang dianalisis ini adalah jaringan jalan, drainase, air bersih, sanitasi dan persampahan (Tabel 4).

Tabel 4. Variabel dan Kriteria Kondisi Prasarana Lingkungan (Hasil Analisis, 2018)

\begin{tabular}{|c|c|c|c|c|c|c|}
\hline Kondisi Jalan & Drainase & Sanitasi & Air Bersih & Persampahan & Kriteria & $\begin{array}{l}\text { Harkat } \\
\text { (Skor) }\end{array}$ \\
\hline $\begin{array}{lr}\text { Jika }>50 \% & \text { jalan } \\
\text { pada } & \text { blok } \\
\text { permukiman } & \\
\text { tersebut } & \text { telah } \\
\text { diaspal } & \text { atau } \\
\text { semen dan } & \text { tidak } \\
\text { terdapat } & \\
\text { genangan air } & \\
\end{array}$ & $\begin{array}{l}>50 \% \\
\text { berfungsi } \\
\text { dengan } \\
\text { baik }\end{array}$ & $\begin{array}{l}>50 \% \text { memiliki } \\
\text { WC, dilengkapi } \\
\text { dengan } \\
\text { septitank kondisi } \\
\text { baik (tidak } \\
\text { meluap) }\end{array}$ & $\begin{array}{l}>50 \% \text { PAM } \\
\text { dan Sumur }\end{array}$ & $\begin{array}{l}>50 \% \text { membuang } \\
\text { sampah pada } \\
\text { tempat } \\
\text { pembuangan }\end{array}$ & Baik & 3 \\
\hline $\begin{array}{l}\text { Jika } 25 \%-50 \% \text { jalan } \\
\text { pada blok } \\
\text { permukiman } \\
\text { tersebut belum } \\
\text { diaspal atau } \\
\text { semen dan jarang } \\
\text { tergenang air }\end{array}$ & $\begin{array}{l}25 \%-50 \% \\
\text { berfungsi } \\
\text { dengan } \\
\text { baik }\end{array}$ & $\begin{array}{lr}25 \% \quad- & 50 \% \\
\text { memiliki } & \text { WC, } \\
\text { dilengkapi } & \\
\text { dengan } & \\
\text { septitank } & \text { kondisi } \\
\text { cukup baik } & \text { (jarang meluap) }\end{array}$ & $\begin{array}{l}25 \%-50 \% ; \\
\text { PAM dan } \\
\text { Sumur }\end{array}$ & $\begin{array}{ll}25 \% \quad- & 50 \% \\
\text { membuang } & \\
\text { sampah pada } \\
\text { tempat } \\
\text { pembuangan }\end{array}$ & $\begin{array}{l}\text { Cukup } \\
\text { Baik }\end{array}$ & 2 \\
\hline Jika $\quad<25 \%$ jalan & $25 \%$ & $<25 \%$ memiliki & $25 \%$ & $<25 \%$ membuang & Buruk & 1 \\
\hline
\end{tabular}




\begin{tabular}{|c|c|c|c|c|}
\hline $\begin{array}{lr}\text { pada } & \text { blok } \\
\text { permukiman } & \\
\text { tersebut } & \text { telah } \\
\text { diaspal } & \text { atau } \\
\text { semen } & \text { dan } \\
\text { terdapat } & \\
\text { genangan air } & \end{array}$ & $\begin{array}{l}\text { berfungsi } \\
\text { dengan } \\
\text { baik }\end{array}$ & $\begin{array}{l}\text { WC, dilengkapi } \\
\text { dengan } \\
\text { septitank kondisi } \\
\text { kurang baik } \\
\text { (sering meluap) }\end{array}$ & $\begin{array}{l}\text { PAM, } \\
\text { sumur, } \\
\text { sumber lain }\end{array}$ & $\begin{array}{l}\text { sampah pada } \\
\text { tempat } \\
\text { pembuangan } \\
\text { tanpa } \\
\text { penampungan } \\
\text { membuang } \\
\text { sampah }\end{array}$ \\
\hline
\end{tabular}

2.3 Analisis bentuk adaptasi masyarakat permukiman pesisir

Analisis bentuk adaptasi masyarakat permukiman pesisir digunakan untuk mengetahui bentuk atau upaya masyarakat pesisir dalam menghadapi bencana banjir rob. Teknik analisis yang digunakan adalah analisis skoring dengan variabel atau data meliputi kemampuan masyarakat dalam memperbaiki hunian (Tabel II.5).

Tabel 5. Variabel dan Kriteria Bentuk Adaptasi (Hasil Analisis, 2018)

\begin{tabular}{|l|c|c|}
\hline \multicolumn{1}{|c|}{ Kriteria } & Klasifikasi & $\begin{array}{c}\text { Harkat } \\
\text { (Skor) }\end{array}$ \\
\hline Tidak melakukan upaya perbaikan (<13\%) & Baik & 3 \\
\hline Tidak melakukan upaya perbaikan (13\%-26\%) & Cukup Baik & 2 \\
\hline Tidak melakukan upaya perbaikan (27\%-40\%) & Buruk & 1 \\
\hline
\end{tabular}

2.4 Analisis hubungan karakteristik permukiman dengan bentuk adaptasi masyarakat pesisir

Analisis ini digunakan untuk mengetahui hubungan karakteristik permukiman dengan bentuk adaptasi masyarakat pesisir terhadap rob. Analisis ini dilakukan dengan mengolah hasil dari analisis karakteristik permukiman dan bentuk adaptasi masyarakat pesisir. Teknik analisis yang digunakan adalah analisis korelasi spearman.

\section{HASIL DAN PEMBAHASAN}

3.1 Analisis Perubahan Penggunaan Lahan Permukiman

Wilayah Kecamatan Genuk yang menjadi kawasan rawan bencana rob memiliki total luas wilayah 16.022.640 $\mathrm{m}^{2}$ dengan luas lahan permukiman sebesar $3.899 .948 \mathrm{~m}^{2}$ dan lahan non permukiman seluas $12.122 .690 \mathrm{~m}^{2}$. Berikut luas penggunaan lahan permukiman di tiap kelurahan yang berada di Kecamatan Genuk pada tahun 2007 dan 2017 dapat dilihat pada Tabel 6.

Tabel 6. Perubahan Luas Lahan Permukiman Tahun 2007-2017 (Hasil Analisis, 2018)

\begin{tabular}{|c|c|c|c|c|c|c|c|c|c|c|c|}
\hline \multirow{3}{*}{ No } & \multirow{3}{*}{ Kelurahan } & \multicolumn{4}{|c|}{2007} & \multicolumn{4}{|c|}{2017} & \multirow{2}{*}{\multicolumn{2}{|c|}{$\begin{array}{c}\text { Perubahan } \\
\text { Lahan Permukimar }\end{array}$}} \\
\hline & & \multicolumn{2}{|c|}{ Non Permukiman } & \multicolumn{2}{|c|}{ Permukiman } & \multicolumn{2}{|c|}{ Non Permukiman } & \multicolumn{2}{|c|}{ Permukiman } & & \\
\hline & & $\left(\mathrm{m}^{2}\right)$ & $(\%)$ & $\left(\mathrm{m}^{2}\right)$ & $(\%)$ & $\left(m^{2}\right)$ & $(\%)$ & $\left(\mathrm{m}^{2}\right)$ & $(\%)$ & $\left(m^{2}\right)$ & (\%) \\
\hline 1 & Muktiharjo Lor & $1,156,685 \cdot 5$ & 9.22 & $161,601.8$ & 4.64 & $1,125,813.00$ & 9.29 & $192,474.2$ & 4.94 & $30,872.4$ & 0.29 \\
\hline 2 & Gebangsari & $733,588.2$ & 5.85 & $630,332.2$ & 18.10 & $721,587.90$ & 5.95 & $642,332.5$ & 16.47 & $12,000 \cdot 3$ & -1.63 \\
\hline 3 & Genuksari & $845,390.1$ & 6.74 & $163,098.6$ & 46.85 & $632,427.60$ & 5.22 & $1,885,465$ & 48.35 & 254,479 & 1.50 \\
\hline 4 & Banjardowo & $2,071,178.1$ & 16.52 & $715,396.8$ & 20.55 & $1,976,950.00$ & 16.31 & $809,624.4$ & 20.76 & $94,227.6$ & 0.21 \\
\hline 5 & Trimulyo & $3,159,555.9$ & 25.19 & $192,365 \cdot 7$ & $5 \cdot 53$ & $3,150,304.00$ & 25.99 & $201,618.1$ & 5.17 & $9,252.4$ & -0.36 \\
\hline 6 & $\begin{array}{l}\text { Terboyo } \\
\text { Wetan }\end{array}$ & $1,830,142.7$ & 14.59 & $133,049 \cdot 4$ & 3.82 & $1,824,968.00$ & 15.05 & $138,223.6$ & 3.54 & $5,174.24$ & -0.28 \\
\hline 7 & $\begin{array}{l}\text { Terboyo } \\
\text { Kulon }\end{array}$ & $2,744,514.7$ & 21.88 & $17,852.8$ & 0.51 & $2,734,039.00$ & 22.55 & $30,210.52$ & 0.77 & $12,357.7$ & 0.26 \\
\hline & Jumlah & $1.254 .105,522$ & 100 & $3,481,584.74$ & 100 & $12,122,690$ & 100 & $3,899,948.3$ & 100 & $418,363.64$ & 0 \\
\hline
\end{tabular}


Terjadi penambahan luas lahan permukiman dalam kurun waktu 10 tahun (2007-2017) sebesar 418.363,64 $\mathrm{m}^{2}$. Pada tahun 2007, luas lahan permukiman hanya menempati 21,73\% dari total luas wilayah di 7 (tujuh) kelurahan di Kecamatan Genuk. Sedangkan pada tahun 2017 luas lahan permukiman mencapai 24,34\% dari luas wilayah keseluruhan. Peningkatan luas lahan permukiman di 7 (tujuh) kelurahan di Kecamatan Genuk mencapai 2,61\%. Sebagian besar peningkatan luas lahan permukiman terjadi di Kelurahan Genuksari sebesar $254.479 \mathrm{~m}^{2}$ (1,50\%). Penambahan intensitas bangunan pada wilayah tersebut dipengaruhi oleh meningkatnya jumlah bangunan informal dan munculnya perumahan baru skala kecil. Penambahan penggunaan lahan permukiman menjadi penyebab bertambahnya kawasan rawan bencana rob di Kecamatan Genuk. Menurut Kodoatie, R.J. dan Sjarief (2005), meningkatnya pengurukan tanah dan pembebanan bangunan berat untuk permukiman di kawasan pesisir menjadi salah satu penyebab penurunan muka tanah dan rob. Sedangkan paling sedikit perubahan luas lahan permukiman terletak di Kelurahan Terboyo Wetan sebesar 5.174,24 $\mathrm{m}^{2}$ (-0,28 \%) dan Kelurahan Trimulyo sebesar 9.252,4 (0,36\%). Hal ini disebabkan karena wilayah tersebut merupakan kawasan rawan bencana rob dengan tingkat ketinggian genangan rob lebih dari 1,5 m sehingga tidak aman untuk tempat tinggal. Perkembangan penggunaan lahan di 7 (tujuh) kelurahan di Kecamatan Genuk pada tahun 2007-2017 dapat dilihat pada Gambar 3 di bawah ini:

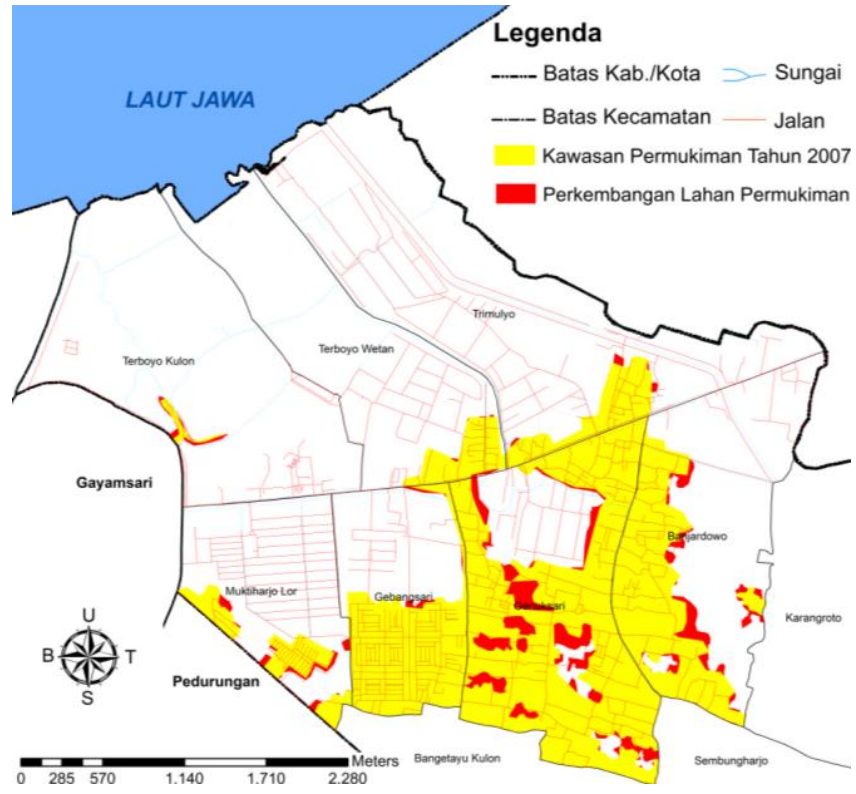

Gambar 3. Peta Perkembangan Lahan Permukiman Tahun 2007-2017 ( Hasil Analisis, 2018)

\subsection{Analisis Karakteristik Permukiman}

\subsubsection{Kondisi fisik permukiman}

Kondisi fisik permukiman hunian di kawasan permukiman pesisir Kecamatan Genuk dapat dilihat dari kepadatan bangunan, luas lantai rumah dan kondisi bangunan. Kepadatan bangunan rata-rata pada permukiman jarang (<40\%) (skor 3) berada di Kelurahan Genuksari, Banjardowo, Trimulyo dan Terboyo Wetan, kepadatan bangunan rata-rata pada permukiman sedang ( $<40 \%-60 \%)$ (skor 2$)$ berada di kawasan permukiman Kelurahan Muktiharjo Lor, dan Gebangsari dan Terboyo Kulon. Luas lantai rumah kawasan permukiman yang layak (skor 3) terletak di Kelurahan Genuksari, luas lantai rumah kawasan permukiman yang cukup layak (skor 2) terletak di Kelurahan Muktiharjo Lor dan Banjardowo. Luas lantai rumah kawasan permukiman yang tidak layak (skor 1) terletak di Kelurahan Gebangsari, Trimulyo, Terboyo Kulon, dan Terboyo Wetan. Sebagian besar tingkat permanensi bangunan tinggi (75\%-87\%) (skor 3) terletak di Kelurahan Muktiharjo Lor dan Genuksari, sedangkan tingkat permanensi bangunan sedang (61\%-74\%) (skor 2) terletak di Gebangsari, Banjardowo dan Terboyo Kulon dan rata-rata rumah yang memiliki kondisi buruk 
(skor 1) terletak di Kelurahan Trimulyo dan Terboyo Wetan. Berdasarkan hasil analisis kondisi fisik permukiman, terdapat 3 kondisi fisik permukiman di 7 (tujuh) kelurahan di Kecamatan Genuk yaitu:

1. Kondisi fisik permukiman baik berlokasi di: Kelurahan Muktiharjo Lor, Kelurahan Banjardowo, dan Kelurahan Genuksari (total skor 7-9).

2. Kondisi fisik permukiman cukup baik berada di Kelurahan Gebangsari, Trimulyo, Kelurahan Terboyo Wetan dan Kelurahan Terboyo Kulon (total skor 4-6). Kawasan permukiman dengan kondisi fisik permukiman cukup baik salah satunya disebabkan karena sebagian besar jumlah tingkat kepadatan permukiman yang cukup tinggi, luas lantai bangunan yang kurang memenuhi standar, dan kondisi material bangunan semi dan non permanen. Selain itu, kondisi fisik permukiman juga masih dinilai kurang baik dikarenakan adanya kerusakan akibat banjir rob di kawasan permukiman pesisir Kecamatan Genuk.

3. Kondisi fisik permukiman kurang baik (skor <4) tidak ditemukan di Kecamatan Genuk.

Distribusi spasial kondisi fisik permukiman Kecamatan Genuk dapat dilihat pada Gambar 4 berikut ini.

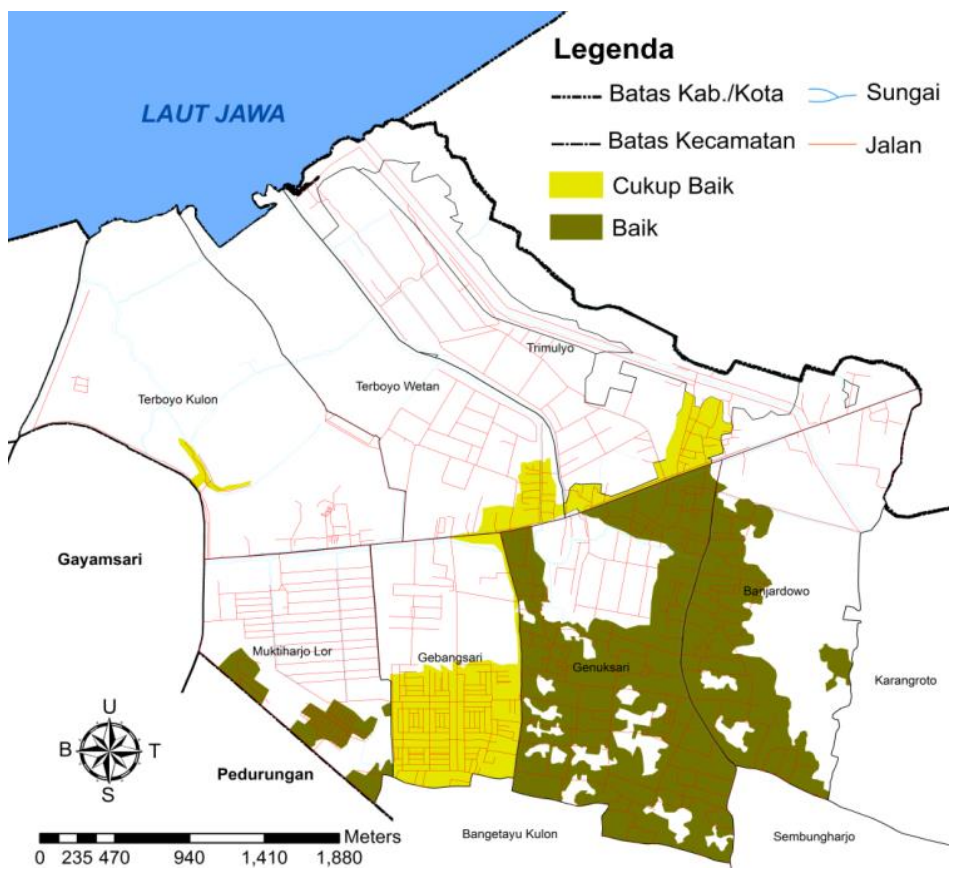

Gambar 4. Kondisi Fisik Permukiman Kecamatan Genuk (Hasil Analisis, 2018)

\subsubsection{Ketersediaan Sarana Lingkungan}

Sarana lingkungan permukiman sebagai fasilitas penunjang untuk mewadahi kegiatan sosial, budaya dan ekonomi dapat meliputi fasilitas pelayanan ekonomi dan perdagangan, fasilitas pelayanan sosial, fasilitas pelayanan kesejahteraan sosial dan fasilitas pelayanan pendukung lainnya (Conyers 1984). Kelurahan yang mempunyai sarana pen1didikan memadai (skor 3) terletak di Kelurahan Terboyo Wetan, Gebangsari, Genuksari dan Kelurahan Banjardowo. Hampir seluruh kelompok umur sekolah dapat merasakan kelengkapan sarana pendidikan di masing-masing kelurahan. Sedangkan sarana pendidikan yang cukup memadai (skor 2) kebutuhan pendidikan kawasan permukiman terletak di Kelurahan Muktiharjo Lor, Trimulyo dan Kelurahan Terboyo Kulon. Sarana pendidikan di kelurahan tersebut dikategorikan cukup memadai dikarenakan jumlahnya sudah cukup melayani seluruh jumlah penduduk. Namun, sarana pendidikan di Kelurahan Trimulyo tergolong tidak layak dikarenakan masih tergenang air rob. Kelurahan yang mempunyai sarana pendidikan kurang memadai (skor 1) tidak terdapat di Kecamatan Genuk dikarenakan hampir setiap kelurahan memiliki jumlah minimal 1 (satu) pendidikan formal yaitu 
pendidikan dasar. Ketersediaan sarana lingkungan dilihat dari ketersediaan sarana pendidikan, kesehatan dan perdagangan.

1. Sarana lingkungan memadai berlokasi di: Kelurahan Muktiharjo Lor, Kelurahan Gebangsari, Kelurahan Genuksari dan Kelurahan Banjardowo (total skor >7).

2. Sarana lingkungan cukup memadai berada di Kelurahan Trimulyo, Terboyo Wetan dan Kelurahan Terboyo Kulon (total skor 5-7). Kawasan permukiman dengan sarana lingkungan cukup memadai salah satunya disebabkan karena sebagian besar jumlah sarana lingkungan masih belum dapat melayani keseluruhan jumlah penduduk atau kelompok lingkungan yang ada seperti sarana pendidikan dan sarana kesehatan. Selain itu, kondisi sarana lingkungan yang tersedia juga masih dinilai kurang baik dikarenakan adanya kerusakan akibat banjir rob di kawasan permukiman pesisir Kecamatan Genuk.

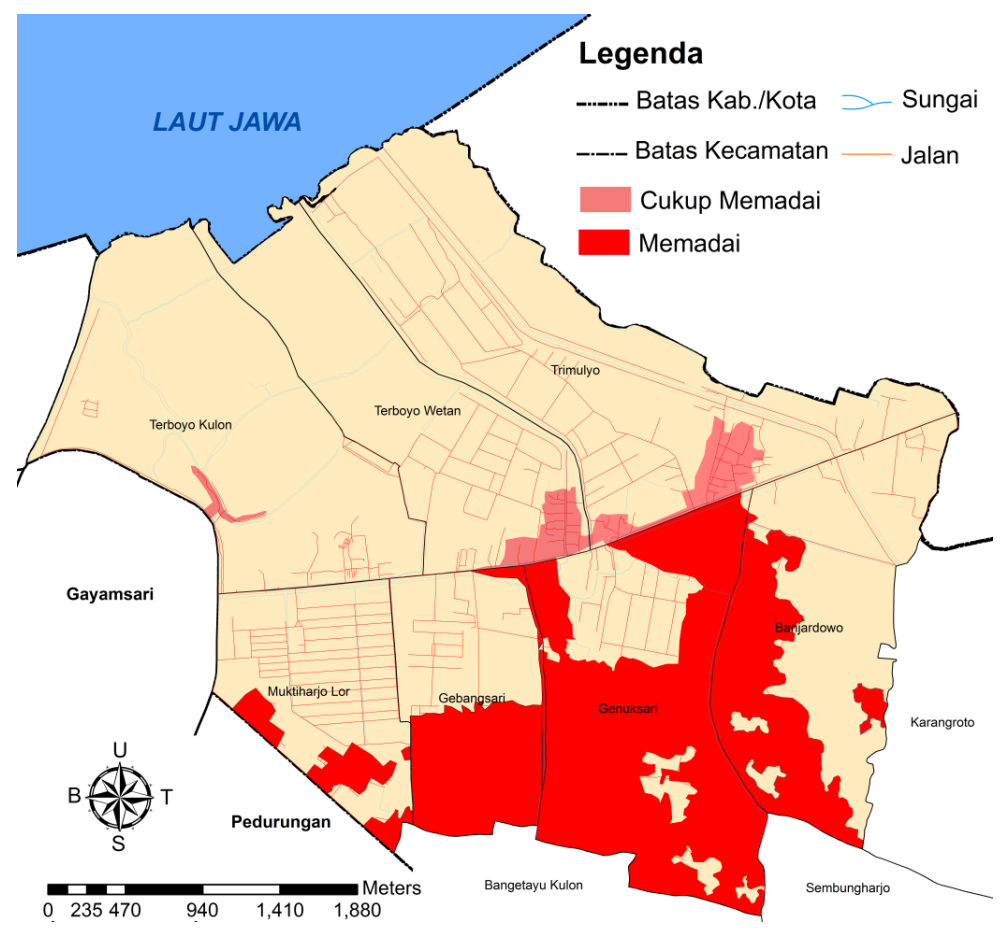

Gambar 5. Ketersediaan Sarana Lingkungan Permukiman Kecamatan Genuk (Hasil Analisis, 2018)

\subsubsection{Ketersediaan Prasarana Lingkungan}

Ketersediaan prasarana lingkungan dilihat dari ketersediaan prasarana jalan, drainase, air bersih, sanitasi dan persampahan. Berdasarkan hasil analisis kondisi fisik permukiman, terdapat 3 kondisi fisik permukiman di 7 (tujuh) kelurahan di Kecamatan Genuk yaitu:

1. Kondisi prasarana lingkungan permukiman yang baik berlokasi di: Kelurahan Muktiharjo Lor, Kelurahan Gebangsari, Kelurahan Genuksari, Kelurahan Banjardowo dan Kelurahan Terboyo Wetan. (total skor 13-18)

2. Kondisi prasarana lingkungan permukiman tersedia cukup baik berada di Kelurahan Trimulyo dan Kelurahan Terboyo Kulon (total skor 7-12). Kawasan permukiman dengan prasarana lingkungan tersedia dan kondisi cukup baik salah satunya disebabkan karena sebagian besar kondisi prasarana lingkungan masih belum dapat baik yaitu kondisi jaringan jalan rusak dan tergenang air, drainase yang sering tersumbat, dan jaringan persampahan yang belum dapat dikelola dengan baik.

3. Kondisi kawasan permukiman dengan kondisi prasarana lingkungan kurang baik (total skor <7) tidak ditemukan di Kecamatan Genuk.

Distribusi spasial ketersediaan prasarana lingkungan kawasan permukiman Kecamatan Genuk dapat dilihat pada Gambar 6 berikut ini. 


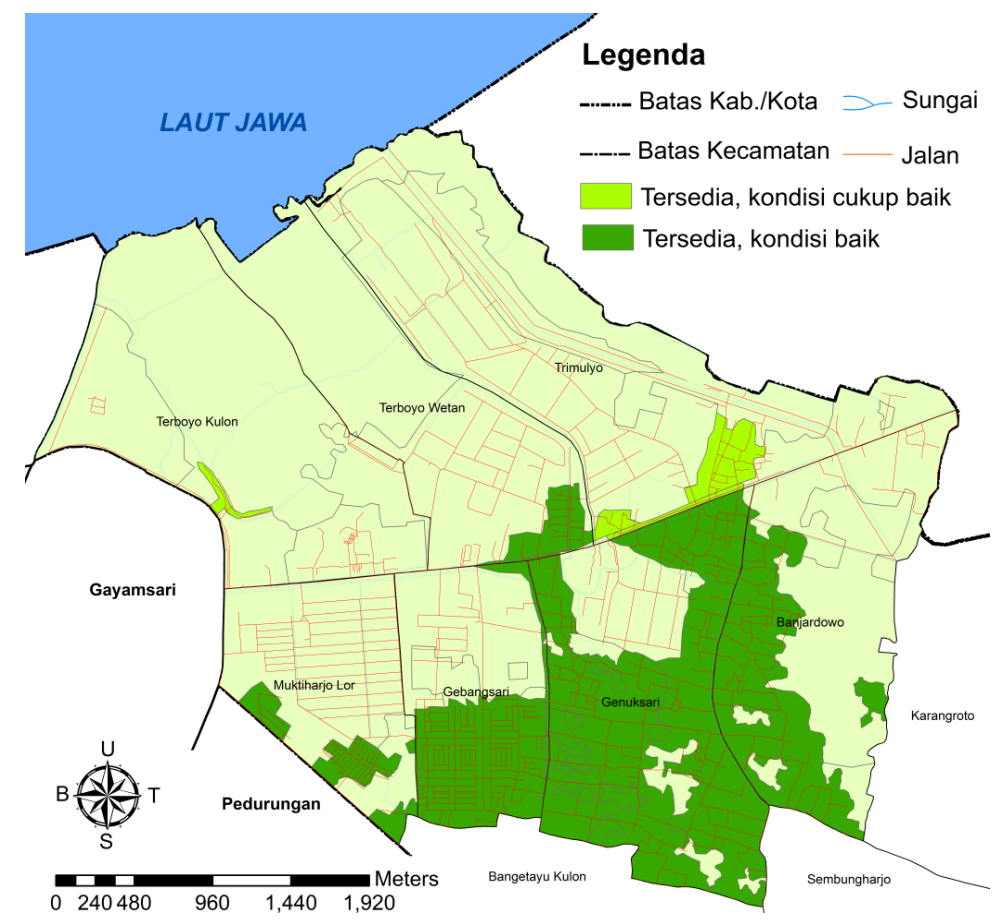

Gambar 6. Ketersediaan Prasarana Lingkungan Permukiman Kecamatan Genuk (Hasil Analisis, 2018)

\subsubsection{Karakteristik Permukiman}

Hasil dari klasifikasi karakteristik permukiman di kawasan pesisir Kecamatan Genuk dapat dibedakan menjadi 2 karakteristik yaitu sebagai berikut:

> Karakteristik 1 (baik, skor = 3): kawasan permukiman di Kelurahan Muktiharjo Lor, Kelurahan Gebangsari, Kelurahan Genuksari dan Kelurahan Banjardowo.

Karakteristik 2 (cukup baik, skor $=2$ ): kawasan permukiman di Kelurahan Trimulyo, Kelurahan Terboyo Wetan dan Kelurahan Terboyo Kulon.

Perbedaan karakteristik fisik lingkungan permukiman dipengaruhi oleh karakteristik fisik permukiman perkotaan yang baik yang dilengkapi dengan ketersediaan sarana dan prasarana lingkungan dalam kondisi yang memadai. Karakteristik pertama memiliki kondisi fisik hunian yang baik dengan ketersediaan sarana dan prasarana yang memadai sedangkan karakteristik kedua memiliki kondisi fisik hunian yang buruk seperti jenis material bangunan semi/ non permanen, ketersediaan sarana kesehatan belum memadai dan kondisi prasarana lingkungan seperti jalan, drainase dan sanitasi yang buruk. Distribusi karakteristik fisik permukiman di Kecamatan Genuk dapat dilihat pada Gambar 7. berikut ini. 


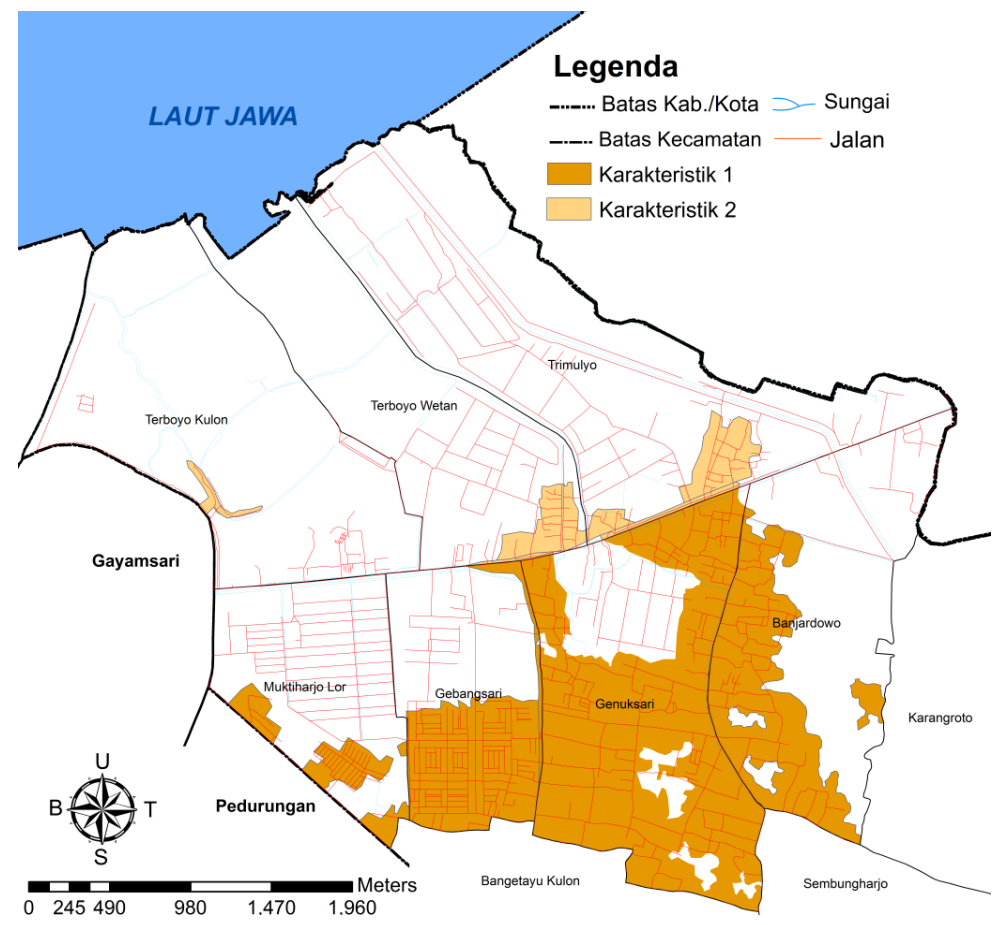

Gambar 7. Karakteristik Permukiman di Kecamatan Genuk (Hasil Analisis Penyusun, 2018)

\subsection{Bentuk Adaptasi Masyarakat}

Terdapat 3 bentuk adaptasi masyarakat pesisir terhadap bencana rob di Kecamatan Genuk yaitu membangun rumah menjadi dua lantai, meninggikan lantai bangunan, dan tidak melakukan upaya perbaikan. Adaptasi masyarakat terhadap rob sebelumnya telah diteliti oleh Marfai and Hizbaron (2011), menghasilkan 4 bentuk fisik adaptasi yaitu memindahkan barang ke tempat yang lebih tinggi, meninggikan lantai mengitungi ketinggian banjir, meningkat bangunan dan membuat tanggul pencegah banjir. Berdasarkan hasil penelitian, kemampuan adaptasi masyarakat terhadap banjir rob yang tergolong tinggi (skor 3) berada di Kelurahan Muktiharjo Lor, Gebangsari, Genuksari dan Kelurahan Terboyo Kulon.

Sebagian besar kondisi ekonomi masyarakat pada wilayah tersebut merupakan masyarakat kelas atas yang memiliki kemampuan tinggi untuk mengubah kondisi bangunan huniannya. Sedangkan masyarakat yang memiliki kemampuan adaptasi adaptasi cukup baik (skor 2) berada di Kelurahan Trimulyo. Secara ekonomi, masyarakat pada wilayah tersebut cukup mampu dalam memperbaiki kondisi bangunan rumah dengan meninggikan lantai bangunan dan memperbaiki fungsi lain. Kelurahan Trimulyo merupakan wilayah yang paling sering merasakan bencana banjir rob. Kondisi rob tersebut yang kemudian secara tidak langsung menuntut masyarakat untuk mengubah kondisi bangunan. Kemampuan adaptasi masyarakat terhadap banjir rob yang tergolong rendah (skor 1) berada di Kelurahan Banjardowo dan Terboyo Kulon. Kemampuan adaptasi di Kelurahan Banjardowo dinilai rendah dikarenakan kondisi banjir rob belum sepenuhnya merusak fisik lingkungan permukiman sehingga upaya adaptasi masyarakat dalam memperbaiki kondisi hunian tergolong rendah. Sedangkan di Kelurahan Terboyo Kulon sebagian besar masyarakat yang tinggal merupakan masyarakat kelas bawah yang tidak memiliki pilihan lain dengan menerima perubahan kondisi lingkungan permukiman akibat rob. 
3.5 Hubungan Karakteristik Permukiman dengan Bentuk Adaptasi Masyarakat Pesisir

Ada atau tidaknya hubungan dapat dilihat dari besarnya nilai koefisien korelasi Spearman yang ditandai dengan simbol $\rho_{\mathrm{s}}$ atau $\mathrm{r}_{\mathrm{s}}$, yaitu ukuran atas kadar/derajat hubungan antara data yang telah disusun menurut peringkat (ranked data) (Supranto 1996). Nilai koefisien korelasi spearman antara karakteristik fisik lingkungan permukiman dengan bentuk adaptasi yaitu 0,342. Nilai tersebut menunjukkan adanya hubungan yang cukup kuat antara dua variabel tersebut (Sarwono 2006). Koefisien korelasi memiliki nilai positif artinya hubungan bentuk adaptasi dengan karakteristik fisik lingkungan permukiman memiliki hubungan yang searah artinya semakin baik karakteristik permukiman maka semakin tinggi pula upaya yang dilakukan masyarakat untuk beradaptasi sehingga masyarakat lebih memilih untuk tetap bertempat tinggal di kawasan permukiman tersebut. Hasil analisis overlay karakteristik permukiman dengan bentuk adaptasi masyarakat terhadap bencana rob di Kecamatan Genuk dapat dilihat pada Gambar 8.

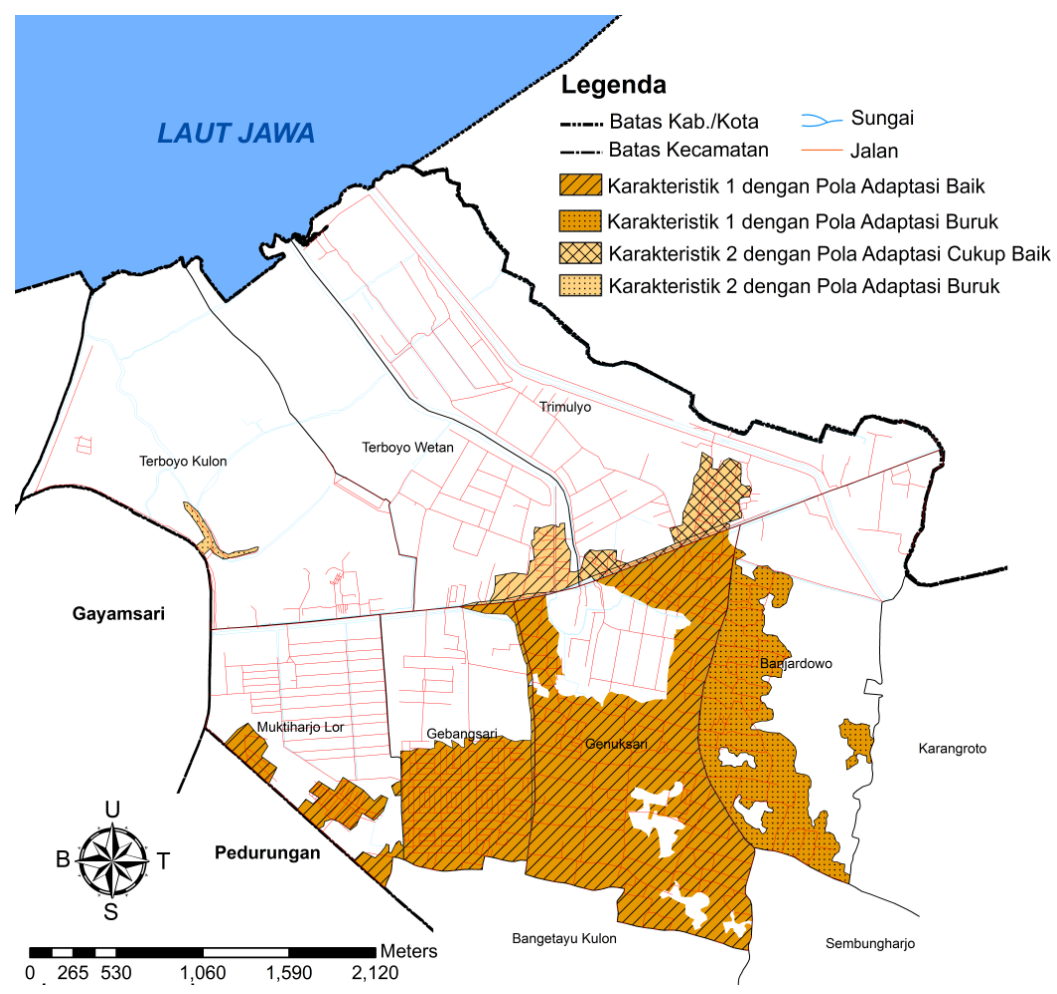

Gambar 8. Peta Hubungan Karakteristik Permukiman dengan Pola Adaptasi Masyarakat di Kecamatan Genuk (Hasil Analisis Penyusun, 2018)

Pada gambar diatas, terdapat 4 (empat) jenis hubungan karakteristik permukiman dengan bentuk adaptasi masyarakat terhadap bencana rob di Kecamatan Genuk. Karakteristik 1 dengan bentuk adaptasi baik berada di Kelurahan Muktiharjo Lor, Kelurahan Gebangsari, Kelurahan Genuksari. Hal ini mengindikasikan bahwa terdapat hubungan antara karakteristik permukiman yang baik dengan bentuk adaptasi yang baik juga. Menurut Holahan (1982), lingkungan dan manusia juga memiliki keterkaitan yang erat, dimana lingkungan memengaruhi manusia dan manusia juga memengaruhi lingkungan. Pada wilayah tersebut, seringnya perbaikan kondisi sarana dan prasarana lingkungan permukiman memengaruhi besarnya upaya masyarakat beradaptasi seperti meningkat bangunan dan meninggikan lantai bangunan. Sebagian besar masyarakat pada wilayah tersebut juga merupakan masyarakat kelas atas yang memiliki kemampuan untuk memperbaiki kondisi lingkungan permukimannya. Sedangkan Kelurahan Banjardowo memiliki karakteristik 1 dengan bentuk adaptasi buruk disebabkan karena kondisi banjir rob belum sepenuhnya merusak fisik lingkungan permukiman sehingga upaya adaptasi masyarakat dalam memperbaiki kondisi hunian tergolong rendah. 
Karakteristik 2 dengan bentuk adaptasi cukup baik berada di Kelurahan Terboyo Wetan dan Kelurahan Trimulyo. Hal ini mengindikasikan bahwa terdapat hubungan antara karakteristik permukiman yang tergolong cukup baik dengan bentuk adaptasi masyarakat yang cukup baik juga. Menurut York, Reinhold, dan Guilfoil (1991), kemampuan adaptasi memiliki perbandingan yang tegak lurus dengan tekanan lingkungan tempat tinggal masyarakat. Sama halnya dengan wilayah tersebut, kondisi fisik permukiman yang mengalami kerusakan cukup parah secara tidak langsung memengaruhi keinginan masyarakat untuk memperbaiki kondisi huniannya. Hal ini juga didukung dengan kondisi masyarakat yang sebagian besar memiliki keterbatasan ekonomi untuk berpindah dari tempat tinggal saat ini. Sedangkan Kelurahan Terboyo Kulon memiliki karakteristik 2 dengan bentuk adaptasi buruk. Bagi masyarakat yang ingin bertahan pada lingkungannya harus dapat menyesuaikan diri dengan berbagai tindakan adaptasi (Banerjee 1961). Berbeda kondisinya dengan masyarakat yang memiliki kemampuan ekonomi yang rendah. Masyarakat golongan ekonomi bawah cenderung menerima perubahan kondisi fisik lingkungan permukiman akibat bencana rob karena tidak mempunyai pilihan lain.

\section{KESIMPULAN}

Dalam penelitian ini aspek fisik digunakan sebagai faktor utama penentu bentuk adaptasi masyarakat terhadap rob. Hasil penelitian menunjukkan bahwa terdapat penambahan luas penggunaan lahan permukiman di 7 (tujuh) kelurahan di Kecamatan Genuk selama kurun waktu 10 tahun (2007-2017) sebesar 418.363,64 $\mathrm{m}^{2}$. Penambahan penggunaan lahan permukiman menjadi penyebab bertambahnya kawasan rawan bencana rob di Kecamatan Genuk dikarenakan meningkatnya pengurukan tanah dan pembebanan bangunan berat untuk pembangunan permukiman. Berdasarkan kondisi fisik lingkungan permukiman ditemukan 2 (dua) karakteristik permukiman yang berbeda. Karakteristik pertama memiliki kondisi fisik hunian yang baik dengan ketersediaan sarana dan prasarana yang memadai sedangkan karakteristik kedua memiliki kondisi fisik hunian yang buruk seperti jenis material bangunan semi/ non permanen, ketersediaan sarana kesehatan belum memadai dan kondisi prasarana lingkungan seperti jalan, drainase dan sanitasi yang buruk. Bencana rob yang terus menerus terjadi memengaruhi timbulnya bentuk adaptasi di Kecamatan Genuk. Terdapat 3 bentuk adaptasi masyarakat dalam memperbaiki kondisi bangunannya yaitu meningkat bangunan menjadi dua lantai, meninggikan seluruh atau sebagian lantai bangunan, dan menerima perubahan kondisi hunian atau tidak melakukan upaya perbaikan terhadap kondisi huniannya. Terdapat hubungan yang kuat antara karakteristik fisik permukiman dengan bentuk adaptasi masyarakat terhadap bencana rob di Kecamatan Genuk (nilai koefisien korelasi $=0,535$ ). Kondisi fisik lingkungan yang nyaman memengaruhi masyarakat untuk tetap bertempat tinggal pada wilayah tersebut dengan cara melakukan upaya adaptasi memperbaiki kondisi bangunan huniannya.

\section{PERNYATAAN RESMI}

Penelitian ini dilakukan dalam rangka menyelesaikan studi sarjana di Departemen Perencanaan Wilayah dan Kota, Universitas Diponegoro. Terimakasih kepada pengelola Kecamatan Genuk, BPS Kota Semarang, BAPPEDA Kota Semarang, Departemen Perencanaan Wilayah dan Kota sebagai institusi yang telah memberikan kesempatan dalam menyelesaikan penelitian ini. Terimakasih juga kepada seluruh author artikel dan text book yang telah penulis gunakan sebagai sitasi penelitian ini.

\section{REFERENSI}

Adger, W. Neil, and Katharine Vincent. 2005. "Uncertainty in Adaptive Capacity." Comptes Rendus Geoscience 337 (4):399-410. doi:10.1016/j.crte.2004.11.004.

Arta, Febrina Sri, and Bitta Pigawati. 2015. "The Patterns and Characteristics of Peri-Urban Settlement in East Ungaran District, Semarang Regency." Geoplanning: Journal of Geomatics and Planning 2 (2): 10315. doi:10.14710/geoplanning.2.2.103-115.

Banerjee, Anuradha. 1961. Environment, Population, and Human Settlements of Sundarban Delta. New Delhi : 
Concept Pub. Co.. 1998424 p. : ill., maps ; $22 \mathrm{~cm}$.

Conyers, D. and P. Hills. 1984. An Introduction to Development Planning in the Third World.

Holahan, Charles J. 1982. "Environmental Psychology." In . New York : Random House.

Jaitman, Laura, and Jose Brakarz. 2013. "Evaluation of Slum Upgrading Programs. Literature Review and Methodological Approaches." Technical Note, Inter-American Development Bank, Institutions for Development Sector (IFD), no. November.

Jens C. Sorensen, Scott T. McCreary. 1990. Institutional Arrangements for Managing Coastal Resources and Environments.

Kodoatie, R.J. dan Sjarief, Rustam. 2005. Pengelolaan Sumber Daya Air Terpadu. Andi, Yogyakarta.

Lins-de-Barros, Flavia Moraes. 2017. "Integrated Coastal Vulnerability Assessment: A Methodology for Coastal Cities Management Integrating Socioeconomic, Physical and Environmental Dimensions Case Study of Região Dos Lagos, Rio de Janeiro, Brazil." Ocean \& Coastal Management 149. Elsevier Ltd: 1-11. doi:10.1016/j.ocecoaman.2017.09.007.

Marfai, Muh Aris, and Dyah R. Hizbaron. 2011. "Community's Adaptive Capacity due to Coastal Flooding in Semarang Coastal City, Indonesia." Analele Universitatii Din Oradea - Seria Geografie 1 (2): 209-21.

Moran, Emilio F. 2018. Human Adaptability: An Introduction to Ecological Anthropology. Human Adaptability, Student Economy Edition: An Introduction to Ecological Anthropology. doi:10.4324/9780429493706.

Perlman. 1980. Prehistory of the Oregon Coast.

Pradoto, Wisnu; Piggawati, Bitta. 2014. "Kebertahanan Masyarakat Pesisir Kota Semarang." Jurnal Teknik PWK.

Riska, Novia, and Nany Yuliastuti. 2013. "Bentuk Adaptasi Masyarakat Terhadap Banjir Di Kampung Purwodinatan Dan Jurnatan Kota Semarang." Jurnal Teknik PWK 2 (3): 457-67. doi:10.1017/CBO9781107415324.004.

Sarwono, Jonathan. 2006. Metode Penelitian Kuantitatif Dan Kualitatif. Yogyakarta: Graha Ilmu.

Smit, Barry, and Johanna Wandel. 2006. "Adaptation, Adaptive Capacity and Vulnerability." Global Environmental Change 16 (3): 282-92. doi:10.1016/j.gloenvcha.2006.03.008.

Sugiyono. 2010. Metode Penelitian Pendidikan Pendekatan Kuantitatif, Kualitatif, Dan R\&D. Bandung: Alfabeta.

Supranto. 1996. Statistik: Teori Dan Aplikasi.

Suryanti, Emi Dwi, and Muh Aris Marfai. 2008. "Adaptasi Masyarakat Kawasan Pesisir Semarang Terhadap Bahaya Banjir Pasang Air Laut (Rob)." Jurnal Kebencanaan Indonesia 1 (5): 335-46. http://jurnal.pdii.lipi.go.id/index.php/search.html?act=tampil\%7B\&\%7Did=57096\%7B\&\%7Didc=46.

Syah, Achmad Fachruddin. 2012. "Strategi Adaptasi Masyarakat Pesisir Bangkalan Terhadap Dampak Banjir" 5 (2).

Turner, John F. C., and Robert Fichter. 1972. "Freedom to Build: Dweller Control of the Housing Process." Urban Studies 11 (2): 301. doi:10.1080/00420987420080501.

Wijaya, Arwan Putra, and Sariffudin. 2014. "POLA ADAPTASI MASYARAKAT PESISIR GENUK KOTA SEMARANG," 245-53.

York, New, Van Nostrand Reinhold, and Joanne K Guilfoil. 1991. "Jon Lang â€ $\epsilon^{\mathrm{TM}} \mathrm{S}$ Creating Architectural Theory."

Zhang, Zhonghao, Rui Xiao, Ashton Shortridge, and Jiaping Wu. 2014. "Spatial Point Pattern Analysis of Human Settlements and Geographical Associations in Eastern Coastal China - A Case Study." International Journal of Environmental Research and Public Health 11 (3): 2818-33. doi:10.3390/ijerph110302818.

Badan Penanggulangan Bencana Daerah. 2018. "Daerah Rawan Bencana." http://bpbd.semarangkota.go.id.

Kemenristek RI. 2013. "Modul 3: Analisis Spasial." Pelatihan Open Sources Software Geodatabase, Web Servis, Dan GIS (Model Spasial Open Platform), 1-31. 